\title{
Genesis, Evolution and Indicators of Leadership in the World Economy
}

\author{
Alexey N. Yeletsky*
}

\author{
Scientific and Applied Research Department, Regional Information and Analytical Centre, Sotsialisticheskaya \\ str. 150, office 305, Rostov-on-Don, 344006, Russia
}

\begin{abstract}
The article reflects the results of scientific research on leadership in the world economy. The purpose of the article is to analyze the problems of determining the key factors of the genesis and evolution of this phenomenon, as well as to identify indicators of the leading position of countries in the global economy. The relevance of the topic is due to the current global processes of the structural shifts within the world economic system and trends concerning a new change in the geo-economic leadership. Based on the world-system methodology, the geo-economic approach, as well as the comparative and historical methods in economics, methods of global political economy, the author developed and demonstrated their synergic potential applied to the research of the world economy's evolution. Heuristic possibilities of the methodological-theoretical concept of a geo-economic polarity (including multipolarity) are used. The author concludes that the leadership is characterized by the presence of immanent factors that determine the genesis of becoming a leader. It is substantiated the significance of each of these factors and proved that their effective combination leads to the formation of a leadership in the global economy. The article provides and describes the chronological periodization of leadership, and its universal triggers, which are unique for each specific stage of the world economy's development. It is established the presence of key indicators that reflect this leadership, and emphasizes the change and expansion of the range of these indicators in the process of the evolutionary development of productive forces. It is justified that current leadership tends to geographic dispersion and is expressed in the gradual establishment of a geo-economic multipolarity of the world economy. The article predicts the current change in the nature of geoeconomic leadership itself.
\end{abstract}

Keywords: Leadership in the world economy, growth triggers, economic history, competitiveness, geo-economics, institutions, technological structures.

\section{INTRODUCTION}

The development of various social systems is often characterized by the fact that the activities of a leader or leaders largely determine the general features of the evolution of these systems. The global economy is no exception to this pattern. Throughout the entire period of existence of the world economy as a single system, the leading belt of subjects, the so-called core, and significant periphery were distinguished. The periphery has always been in a secondary, driven, and largely subordinate position in international economic and political relations.

At the same time, one or several leading countries invariably existed in the structure of the world economic core, which, accordingly, also acted as leaders of the entire world economy. In this regard, the development of the world economy is characterized by the presence of the phenomenon of a leadership presented by one or several advanced countries of the world. This leadership periodically changes as the leading centers of the world economy strengthen or weaken, as well as competition from other advanced actors increases. In

*Address correspondence to this author at the Scientific and Applied Research Department, Regional Information and Analytical Centre, Sotsialisticheskaya str. 150, office 305, Rostov-on-Don, 344006, Russia;

E-mail: abahman.aa@yahoo.com this respect, it is relevant to determine the factors of leadership formation in the global economy, the quantitative and qualitative measurement of this leadership and identify the features of its historical evolution. The particular importance of the studied issues is given by the fact that the leading countries, due to their key place in the system of the international division of labor and their proactive transformational impact on international economic relations, always have a significant impact on the development of the entire world economy. Moreover, as society develops, the scale of this influence is gradually increasing.

\section{METHODOLOGY}

The phenomenon of leadership is an object of scientific analysis by domestic and foreign researchers of international economics, as well as related sciences and research areas. In this paper, the author uses the methodology of several important approaches and principles of analysis.

Thus, the article uses the world-system approach and its methodology, developed in detail by such scientists as S. Amin (1974), G. Arrighi (2010), F. Braudel (1984), I. Wallerstein (Wallerstein, 1974; Wallerstein, 1980; Wallerstein, 1989; Wallerstein, 2011), P. Taylor (2007), A. G. Frank (1996), C. ChaseDunn (1979). This methodology is applied in the 
context of considering leadership in the world economy as a particular manifestation of a core-periphery structure. In addition, the world-system approach is used in combination with the historical method of analyzing economic reality, which is reflected in the formation of an evolutionary chronology and periodization of leadership in the world economy.

The historical method, as well as a set of methods of economic comparative studies, is among the most common in the study of macro-historical features of the world economy's development and its individual subjects. This methodology is especially often used in combination with institutionalism. Such integrated approaches applied in this work are based on the methodological basis used in the research of such scientists as, in particular, D. Acemoglu (2012), R.C. Allen (2011), C.P. Kindleberger (1996), A. Maddison (2007), K. Pomeranz (2001).

An important place in the methodology of this study is taken by the geo-economic approach, which has now become one of the basic ones in terms of studying issues related to ensuring the advantageous position of a country or region within the international division of labor, as well as the formation of foreign economic strategies of world economic entities. In addition, the methodology of the geo-economic approach allowed the author to analyze the features of competition for leadership at the global level, the specifics of achieving leadership in the modern world. In this regard, the leadership in the world economy itself is considered by the author from geo-economic positions and is interpreted as geo-economic. In the framework of the study, the author relied on the methodological developments of such scholars in the domain of the geo-economic approach as J. Attali (2011), R. D. Blackwill (2016]), S. S. Lachininskii (2012), E. Luttwak (1990), P. Savona (1997).

Nevertheless, despite a wide range of theoretical and methodological studies on the development of the world economy and the competitive struggle of its subjects, a number of aspects of this problem are insufficiently studied. Thus, the phenomenon of the origin of leadership in the global economy is insufficiently explored; in particular, the issues of determining the major factors for gaining and maintaining this leadership, economic laws governing the growth of the leading positions of the leading subject in the world economic system, the areas of leadership manifestation and, finally, the reasons for the decline of world economic centers. At the same time, issues related to the relationship between the evolution of the entire world economic system and the chronological change of leadership stages, as well as the establishment of patterns between the countries' leadership stages in the world economy and the general evolution of productive forces and production relations in the world remain not fully analyzed. In this regard, this paper reflects the results of an attempted in-depth analysis of world economic leadership in all its manifestations based on the use of the abovementioned methodological approaches.

\section{RESULTS}

\section{Structural and Functional Parameters of Global Economic Leadership}

Having begun to form as a single system, the world economy has acquired its own internal hierarchical structure, which is an immanent property of most complex systems. As a result of the territorial economic and political expansion of the leading European States, geo-economic and geopolitical centers and dependent peripheries naturally emerged at the global level, and center-periphery structure was formed. At the level of center-peripheral relations within the world economy, one global aggregate subject of these interactions is economic leaders who are developed economies (for their era), while the other aggregate subject is developing economies that occupy a secondary position in the world economic system.

The most important category in the current analysis and the key object of research on the evolution of the world economy as a whole is the geo-economic leader or center, which belongs to the leading subjects of world economic dynamics and is a key factor in the system of international economic relations and the international division of labor. The formation and change of leaders of the world economy begins with the Age of Discovery, thanks to which an increasing number of national economies and macro-regions (world-systems) were involved in the international division of labor and international economic relations, which served as the basis and starting point for the development of the world economy.

In general, from the point of view of analyzing the hierarchical structure of the world economy, it is important to note that since its formation, a certain configuration of leadership has existed for each of the stages of its development. To date, eight chronological periods can be distinguished in the evolution of global geo-economic leadership (Table 1). 
Table 1: Institutional and Technological Drivers of the Evolution of Geo-Economic Leadership in the World

\begin{tabular}{|c|c|c|c|}
\hline $\begin{array}{l}\text { Chronological } \\
\text { period }\end{array}$ & Geo-economic centers & Key technologies and industries & Key institutions \\
\hline \multicolumn{4}{|l|}{ Pre-industrial era } \\
\hline $\begin{array}{l}\text { Late } 15^{\text {th }} \text { century - } \\
\text { late } 16^{\text {th }} \text { century }\end{array}$ & Spain and Portugal & Ocean navigation and shipbuilding & $\begin{array}{l}\text { Royal absolutism interested in } \\
\text { overseas expansion }\end{array}$ \\
\hline $\begin{array}{l}\text { Late } 16^{\text {th }} \text { century - } \\
1670 \text { s }\end{array}$ & Netherlands & Shipbuilding, financial and banking sector & $\begin{array}{l}\text { Burgher corporations, banking and } \\
\text { financial institutions, stock } \\
\text { exchanges }\end{array}$ \\
\hline $1670 s-1815$ & $\begin{array}{l}\text { England (since } 1707 \text { - Great } \\
\text { Britain) and France }\end{array}$ & $\begin{array}{l}\text { Craft (manufacture) production - until the } \\
\text { middle of the XVIII century in both countries- } \\
\text { leaders; } \\
\text { 1st technological paradigm based on } \\
\text { machine revolution (textile industry) from the } \\
\text { second half of the XVIII century-in England }\end{array}$ & $\begin{array}{l}\text { In England - parliamentary } \\
\text { monarchy; } \\
\text { in France -late feudal trade and } \\
\text { manufacturing monopolies }\end{array}$ \\
\hline \multicolumn{4}{|l|}{ Industrial era } \\
\hline $\begin{array}{l}1815 \text {-the last } \\
\text { quarter of the } 19^{\text {th }} \\
\text { century }\end{array}$ & Great Britain & $\begin{array}{c}\text { Until the } 1820 \text { s }-1 \text { st technological paradigm; } \\
1820 \text { s-1870s }-2 \text { nd technological paradigm } \\
\text { based on the steam engine (coal mining, } \\
\text { railways) }\end{array}$ & $\begin{array}{l}\text { Large foreign trade companies, } \\
\text { financial and banking structures }\end{array}$ \\
\hline $\begin{array}{c}\text { The last quarter of } \\
\text { the } 19^{\text {th }} \text { century - } \\
1945\end{array}$ & $\begin{array}{l}\text { USA, Germany, Great Britain, } \\
\text { Russia (since } 1922 \text { - USSR), } \\
\text { France, Japan }\end{array}$ & $\begin{array}{l}3^{\text {rd }} \text { technological paradigm. Industries - } \\
\text { ferrous metallurgy, inorganic chemistry, } \\
\text { railway transport, industrial shipbuilding. } \\
\text { From } 1920 \mathrm{~s}-1930 \mathrm{~s} \text {, the beginning of the } 4 \text { th } \\
\text { technological paradigm on the basis of the } \\
\text { internal combustion engine and the conveyor }\end{array}$ & Industrial and banking monopolies \\
\hline $\begin{array}{l}1945 \text { - the } \\
\text { beginning of the } \\
\text { 1990s }\end{array}$ & $\begin{array}{l}\text { USA and USSR, together with } \\
\text { their subordinate economic } \\
\text { blocks }\end{array}$ & $\begin{array}{l}4^{\text {th }} \text { technological structure. Industries - } \\
\text { automotive industry, machine tool industry, } \\
\text { aircraft industry, aerospace engineering, } \\
\text { organic chemistry, oil production and refining, } \\
\text { nuclear energy. } \\
\text { Since the } 1970 \text { s, in the USA - formation of } \\
\text { the 5th technological paradigm based on } \\
\text { microelectronics }\end{array}$ & $\begin{array}{l}\text { In the USA - multinational } \\
\text { corporations (MNCs). } \\
\text { In the USSR - command } \\
\text { structures, state plan and } \\
\text { Communist Party bureaucracy. } \\
\text { In general, within the global } \\
\text { bipolarity - UN and other } \\
\text { international organizations }\end{array}$ \\
\hline \multicolumn{4}{|l|}{ Postindustrial era } \\
\hline $\begin{array}{l}\text { The beginning of } \\
\text { the } 1990 \text { s }-2009\end{array}$ & $\begin{array}{l}\text { USA with its subordinate } \\
\text { spheres of influence }\end{array}$ & $\begin{array}{c}5^{\text {th }} \text { technological paradigm. Industries - ICT- } \\
\text { sector (computers production, } \\
\text { microelectronics), space industry }\end{array}$ & $\begin{array}{l}\text { American and international TNCs, } \\
\text { international financial institutions }\end{array}$ \\
\hline Since 2009 & $\begin{array}{l}\text { USA and Anglo-Saxon allies, } \\
\text { China, EU, India, Russia, } \\
\text { Brazil }\end{array}$ & $\begin{array}{l}\text { Formation of the } 6 \text { th technological paradigm } \\
\text { based on the convergence of ICT, bio, nano } \\
\text { and cognitive technologies. Development of } \\
\text { artificial intelligence, big data, Internet } \\
\text { economy, Internet of things, digitalization }\end{array}$ & $\begin{array}{l}\text { Global capital in the form of global } \\
\text { corporations and banks; state } \\
\text { apparatus of the leading powers }\end{array}$ \\
\hline
\end{tabular}

The change of leadership in the world economic system, as a rule, was marked by significant changes in the development of the world economy, or at least in the key growth impulses of the vanguard group of developed economies. According to the author's position, the genesis of change of geo-economic leadership and, accordingly, the formation of its new configuration in the world economy consists in the presence of an economic model of a new geoeconomic leader characterized by greater efficiency. This efficiency can be expressed in the economic mechanisms themselves, as well as closely related technological, institutional and other factors that often determine the emerging economic advantage of the new center.

In general, geo-economic leadership throughout the evolution of the world economy is based on an optimal effective ratio of base-superstructure factors. These basic factors include a favorable geographical position and an advanced socio-economic system. The superstructure factors that determine geo-economic leadership include an advanced economic paradigm in its theoretical and practical implementation and a favorable geopolitical situation. It is in the aggregate for each specific situation with different degrees of 
influence and severity, the two above-mentioned basic factors and two superstructure factors determine, according to the author's concept, the genesis of gaining leadership in the world economy. All four factors, within the framework of their synergistic influence, ensure the leading positions of the geoeconomic leader, characterized by the activities of advanced institutions and the use of advanced technologies.

At the same time, basic and superstructure factors in the context of ensuring geo-economic leadership of a particular center have a tendency to mutual influence and interconnection. This phenomenon is most fully and vividly expressed in the framework of the interaction of two factors - the advanced socioeconomic system and the advanced economic paradigm. Thus, the socio-economic system related to the base determines the actual level of development of economic life in the state and influences the formation of certain theoretical views of economists in each specific era and in the conditions of economic development of a specific territory. However, having emerged, the economic paradigm related to the superstructure traditionally takes the form of not just theoretical views, but also begins to be implemented in practical aspects and, accordingly, as the economic policy resulting from the theoretical views is implemented, the paradigm in a broad sense begins to have a corrective effect on the socio-economic system as part of the base (Figure 1).

Thus, according to the author's concept, the change in the configuration of geo-economic leadership is accompanied by the triumph of a certain socioeconomic system and economic paradigm that exists and is being implemented in a new global geoeconomic center-leader (or in several leaders). In the conditions of leadership of a given center or centers in the world economy, arising as a result of a change in the configuration of leadership and the stable existence of a new one, this socio-economic system and economic paradigm gradually become dominant within the global economy, at least in the most developed countries of a geo-economic core.

In general, the country is being formed as a kind of "growth pole" of the world economy and the leader of the world economic system as a result of the generation and use of advanced technologies (technological leadership at later stages is manifested in the use of the latest technological paradigm) and the presence of optimal advanced institutions. The result of these aspects, as a rule, is the leadership of the country in labor productivity.

In addition to the issue of leadership change itself, it is very important from the point of view of analyzing the evolution of the world economy to demonstrate the leadership of the geo-economic center in the conditions of stabilization of the new configuration, that is, within a kind of maturity phase as a global leader. In the context of the dominance of a leading country in the world economy, qualitative superiority over other subjects of the world economy finds its due manifestation in quantitative terms. At the same time, this quantitative expression is manifested both in the economic parameters themselves and in the parameters that

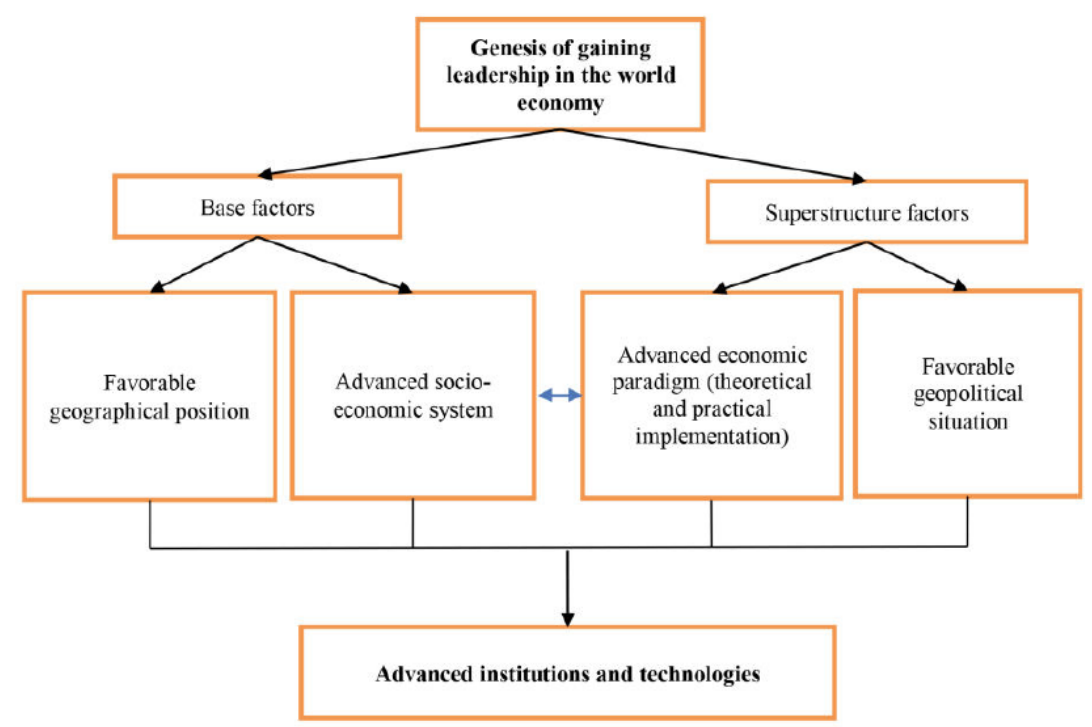

Figure 1: The structure of the factors determining the genesis of gaining geo-economic leadership by a new center (centers) of the world economy. 
reflect geopolitical leadership. In the most general form, these parameters can be grouped into four spheres:

- Technological sphere;

- $\quad$ Paradigm and institutional sphere;

- $\quad$ Macroeconomic sphere;

- $\quad$ Geopolitical spheres.

As for the quantitative reflection of this efficiency demonstrated by the leading center (or centers), these indicators vary for different stages of development of the world economy. Per capita indicators of gross domestic product and industrial production, the level of urbanization, as well as absolute and relative quantitative parameters that reflect research and development expenditures are characterized by a relatively greater universality.

Although the specific parameters that reflect the geo-economic leadership may differ for different periods of the world economy's development, some parameters which are common to all or a significant part of these periods, as well as those that are most general in nature can be distinguished (Table 2).

As a rule, geo-economic leadership is manifested simultaneously in all areas and can be reflected through the following main characteristics:
Leadership in the key area and key technologies for a given configuration of geo-economic leadership and, accordingly, for this stage of development of the world economy;

- $\quad$ Presence of a dynamically growing economy (for the era since the industrial revolution - a large dynamically growing economy);

- Leadership in creating a favorable institutional environment for the most effective use of resources, contributing to the growth of their capitalization;

- $\quad$ Leadership in the military-political sphere (for a multipolar configuration of geo-economic leadership - presence in a group of leaders).

It should be noted that the acquisition of key positions within the mentioned spheres and the possession of characteristics corresponding to these spheres do not occur simultaneously. At the stages of origin and progressive upward evolution, the geoeconomic center may be inferior to various peripheral and semi-peripheral subjects of the world economy in some parameters (especially, gross production indicators). However, within the maturity phase, the leadership of the geo-economic center (or centers) in all selected characteristics and their corresponding parameters is fully realized. Thus, the existing qualitative superiority also induces quantitative

Table 2: Spheres of Geo-Economic Leadership of Center(s) of the World Economy with its Key Parameters

\begin{tabular}{|c|c|}
\hline Area of geo-economic leadership & Key parameters expressing geo-economic leadership \\
\hline Technological sphere & $\begin{array}{l}\text { Share in production and exports within a key area for each era of geo-economic } \\
\text { leadership (for example, an advanced industry or industries for a particular era of the } \\
\text { world economy) } \\
\text { Volume and share in global R\&D expenditures }\end{array}$ \\
\hline Paradigm and institutional sphere & $\begin{array}{c}\text { Presence of the most effective socio-economic system for a specific stage of } \\
\text { development of the world economy } \\
\text { Putting into practice the most advanced forms of management } \\
\text { Presence of the most progressive (or even unique) institutions in the world economy } \\
\text { Presence of the most favorable environment for attracting and using mobile resources } \\
\text { (taking into account the historical context: human resources, investment capital, } \\
\text { advanced knowledge) }\end{array}$ \\
\hline Macroeconomic sphere & $\begin{array}{l}\text { GDP per capita } \\
\text { Level of urbanization } \\
\text { Volume of GDP or/and industrial production, as well as share in the world GDP or global } \\
\text { production (applicable since the industrial era) } \\
\text { Volume of exports } \\
\text { Share in world exports (in world trade in general) } \\
\text { Volume of high-tech exports / share of global exports of high-tech products }\end{array}$ \\
\hline Geopolitical sphere & $\begin{array}{l}\text { Presence of a military-political sphere of influence (including subordinate territories) or } \\
\text { military bloc } \\
\text { Volume and share of global defense expenditures (not in all cases) }\end{array}$ \\
\hline
\end{tabular}


predominance, which is manifested in the leading positions in world exports, production, GDP (typical for epochs since the industrial era), the production of innovative products and exports of high-tech products, the advanced role in world science as a whole.

In addition, at the maturity phase, dominance in the world economy within the framework of base aspects allows the geo-economic center to take a leading place in the global society in terms of superstructure parameters as well. Thus, economic and technological power contributes to progress in the defense sector. Geo-economic centers become leading powers and geopolitical poles, characterized by significant defense expenditures and powerful military capabilities.

Such processes lead to the transformation of a geopolitical balance in the direction of the dominance of these geo-economic centers of the world economy. Global leader (or leaders) of the world economy carry out territorial and political expansion, leading to the formation of their own spheres of influence, the specifics of which depend on a particular stage of development of the world economy (for example, the result of such expansion may be the presence of their own colonial empire or military-political alliance under their dominance). In addition to dominating the military and political sphere, the extension of the geo-economic center's leadership to the superstructure can affect ideological, cultural, global institutional and other components. Thus, at this stage, the dominance of geo-economic centers of the world economy becomes significant in all spheres of global society, which largely confirms the objectivity of the "economic imperialism" concept.

In turn, geo-economic leadership and its accompanying characteristics, including those directly related to global leaders and their dominant economic paradigms, institutional and technological development features, have a significant impact on the development of the world economy as a whole. A change in leadership often leads to deep and comprehensive transformational processes in the world economy.

\section{Modern Transformation of Factors, Structure and Indicators of Leadership in the World Economy}

The increase in the objective significance of the considered phenomena, processes and trends necessitates an analysis of the main parameters that express leadership in the world economy at the present stage of its development. In the post-industrial era, this leadership begins to be characterized by geographical dispersion and multilevel economic specifics. There is an increasing number of criteria that reflect leadership and indicate a significant impact of the economy within the framework of a single global economic system.

However, at present, the value of gross domestic product calculated by purchasing power parity (GDP by PPP) continues to be an integral indicator of the economic power of countries. In addition to this integral parameter, the key quantitative indicators of geoeconomic leadership comprise the volume of exports (including the volume of high-tech exports and exports of intellectual property), as well as R\&D expenditures and their share in GDP.

It should be noted that a clear confirmation of the new round of evolution of geo-economic leadership in the world economy is the fact that starting from 2008, marked by the global crisis, the share of developing countries in the structure of gross world product (GWP) began to exceed the share of developed countries. If in 2000 this ratio was characterized by the fact that developing countries accounted for $43.3 \%$ of GWP (PPP), developed countries - 56.7\%, then in 2019, developing countries accounted for $59.7 \%$, developed countries $-40.3 \%$ (International Monetary Fund, 2020). Since this time, we can talk about the gradual formation of geo-economic multipolarity in the modern world economy.

At present, the Top 10 leading countries in the world economy by GDP (PPP) as calculated by the International Monetary Fund features 5 developing countries and 5 developed ones (Table 3). Moreover, China, which is the largest developing economy, has for several years been confidently the world's first economy in terms of GDP (PPP). In 2019, the process of strengthening the Chinese economy continued, the gap from the US has already amounted to almost 6 trillion USD in GDP (PPP).

One of the most important indicators of modern leadership in the world economy is also the level of technologization of the economy, as evidenced by the growth of global R\&D expenditures. For the period 2006-2018 investments in R\&D increased across all groups of countries (high, middle and low income). It is noteworthy that even the global financial crisis of 20072008 did not have a significant impact on global investment in R\&D. Moreover, in the geo-economic leaders of the world economy, gross domestic expenditures on research and development grew more 
Table 3: Top 10 Leading Countries in the World Economy by GDP (PPP) in 2019

\begin{tabular}{|c|c|c|c|}
\hline Rank & Country & GDP (PPP) in 2019, bln US dollars & Share in the world GDP (PPP) in 2019, \% \\
\hline \hline 1 & China & 27307.0 & 19.2 \\
\hline 2 & United States & 21427.7 & 7.8 \\
\hline 3 & India & 11043.2 & 4.0 \\
\hline 4 & Japan & 5711.9 & 3.1 \\
\hline 5 & Germany & 4443.6 & 3.1 \\
\hline 6 & Russia & 4390.0 & 2.6 \\
\hline 7 & Indonesia & 3735.6 & 2.5 \\
\hline 8 & Brazil & 3480.5 & 2.2 \\
\hline 9 & United Kingdom & 3162.4 & 2.2 \\
\hline 10 & France & 3061.8 & \\
\hline
\end{tabular}

rapidly compared with the dynamics of GDP growth. This led to an increase in global R\&D intensity from $1.94 \%$ in 2007 to $2.22 \%$ of world GDP in 2017 [The World Bank Group, 2020]. At the same time, the OECD countries are the flagships of the R\&D financing process. US spending makes up $2.84 \%$ of GDP (PPP), Japan - 3.50\%; and South Korea shows the largest share of expenditures on R\&D in the structure of GDP$4.35 \%$. At the same time, the two largest economies in the world are unequivocal leaders in gross expenditures on R\&D, and the gap between them is already quite small (Table 4 ).

The greatest interest in terms of expenditures on $R \& D$ is manifested in the industries or sectors of the economy that are currently critical for forming the core of a new technological paradigm: biotechnology, space technology, nanotechnology, fine chemistry, the development of new means of communication, digital networks, computer programs, genetic engineering, space exploration, and CALS-technologies.

The volume of exports continues to be a significant indicator of geo-economic leadership (Table 5), which indicates the level of integration of the country into the global economic processes. It is those countries that have the largest shares in total exports, have the most competitive economic specialization and receive significant state budget revenues. In the end, these export revenues cause partial reinvestment of profits and a gradual increase in the technology of exports of the leading countries. In addition, from the point of view of geo-economic leadership in the information age, not only the leading positions in total merchandise exports are significant, but also in the high-technology exports. This group of exports is the most technologically intensive, requiring highly qualified labor resources and advanced equipment. Besides, it is in the framework of

Table 4: Gross Expenditures on R\$D in Geo-Economic Leaders of the World Economy in 2019

\begin{tabular}{|c|c|c|c|}
\hline \multirow{2}{*}{\multicolumn{2}{|c|}{ Country }} & \multicolumn{2}{c|}{ 2019 (Estimated) } \\
\cline { 2 - 4 } & & Gross expenditures on R\&D (PPP), bIn US dollars & Share in GDP (PPP), \% \\
\hline \hline 1 & United States & 596.58 & 2.84 \\
\hline 2 & China & 532.80 & 3.98 \\
\hline 3 & Japan & 190.65 & 2.84 \\
\hline 4 & Germany & 128.32 & 0.86 \\
\hline 5 & India & 95.79 & 4.35 \\
\hline 6 & South Korea & 90.27 & 2.25 \\
\hline 7 & France & 69.08 & 1.50 \\
\hline 8 & Russia & 61.43 & 1.73 \\
\hline 9 & United Kingdom & 53.17 & 1.16 \\
\hline 10 & Brazil & 39.40 & \\
\hline
\end{tabular}


Table 5: Top 10 Leading Countries in the World Economy by Total Goods Exports and High-Technology Exports in 2018

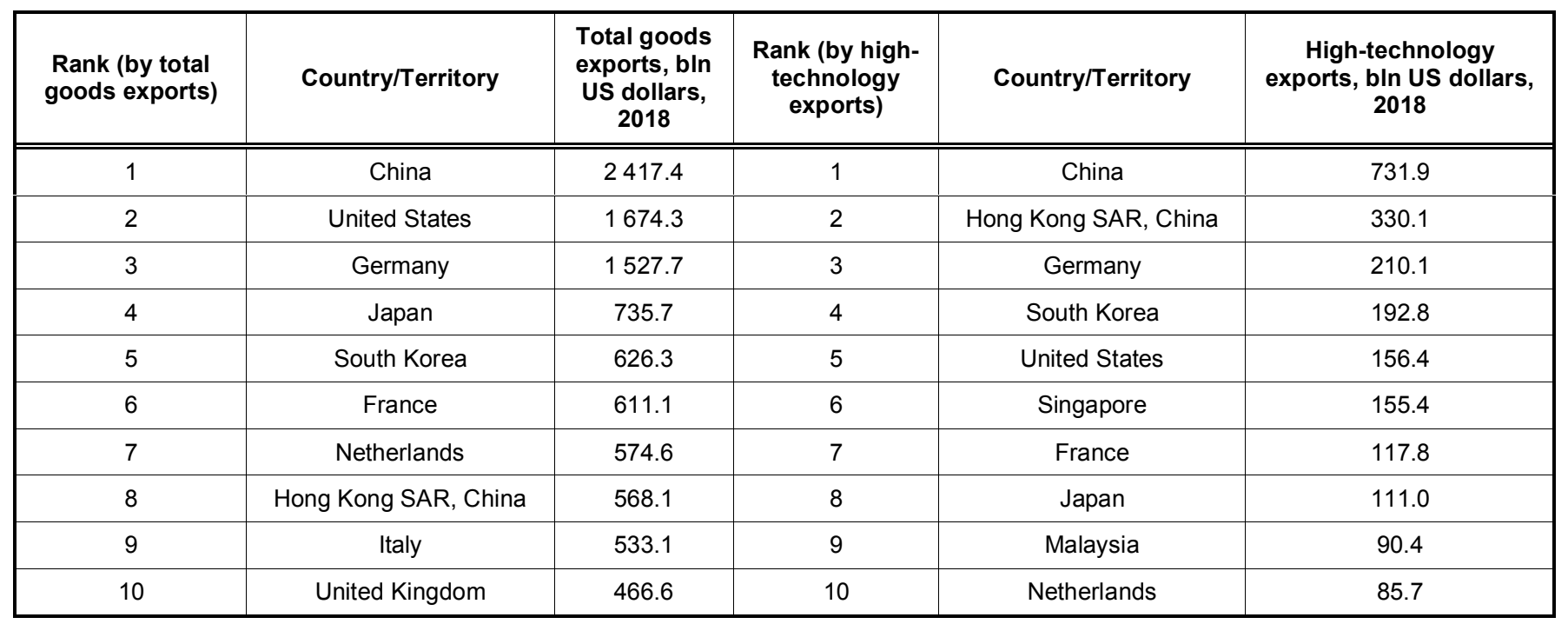

high-technology exports that the highest added value is created, and a country exporting a large volume of high-tech products occupies the most advanced and profitable positions in the international division of labor.

Thus, the dominance of a country within the framework of the above-mentioned key indicators mostly reflects the configuration of leadership in the modern world economy. Today, from the point of view of leadership in the world economy, there is a pronounced geo-economic multipolarity (something similar, although in the conditions of the industrial era, existed at the end of the 19th century and the first half of the 20th century). It is noteworthy that in a postindustrial society, geo-economic leaders include not only geopolitical hegemons, but also relatively small countries that have achieved outstanding economic success. It is these states that demonstrate the new nature of leadership in the world economy, its gradual geographical dispersion, and the prevalence of geoeconomics over geopolitics.

\section{CONCLUSION}

Determining the genesis key factors and evolution of this phenomenon is a critical issue which have been analyzed in this work. Subsequently indicators of the leading position of countries in the global economy have been identified. Ultimately, the main factors of leadership formation are identified in the paper, among which the most stable and comprehensive are the technological and institutional aspects. Within the history of the world economy, 8 consecutive chronological periods of geo-economic leadership are distinguished.
In general, geo-economic leadership, expressed in the form of a pronounced center or centers of the world economy, is due to both qualitative and quantitative attributes. As society evolves, leadership in the global economy begins to be characterized by a wide variety of these attributes. At the same time, 4 comprehensive spheres with their specific indicators of geo-economic leadership are justified.

The pattern has been established that the more global and interdependent the world economic system is, the more significant the transformational impact on the vectors of its development is exerted by a change of geo-economic leadership. The author came to the conclusion that the specificity of leadership and the depth of its influence on the world economic processes are steadily increasing as the economic evolution of society and scientific and technological progress develop and move forward. At the same time, it is justified that the progressive development of society, and especially technological progress, have a significant impact on changes in the essence of leadership itself, on the range and economic quality of its manifestation. Thus, this dependence is recognized as mutual and increasing with the progressive evolution of economic civilization.

It has been revealed that the current stage of the struggle for geo-economic leadership continues in many dimensions. At the same time, the main indicators of geo-economic power are GDP (PPP), export volumes (especially high-tech exports) and expenditures on R\&D, which together reflect the effectiveness of the pursued economic policy, the 
rational and efficient use of resources, and the level of competitiveness of specialization industries.

\section{ACKNOWLEDGEMENTS}

This paper was created within the project "Fundamental laws and technologies for using evolutionary-genetic and institutional mechanisms of economic growth and development" supported by Russian Foundation for Basic Research. Project registration number 20-010-00323 A

\section{REFERENCES}

Acemoglu, Daron, and James A. Robinson. 2012. "Why nations fail: The origins of power, prosperity, and poverty." Currency. https://doi.org/10.1355/ae29-2j

Allen, Robert C. 2011. "Global economic history: a very short introduction." 282. Oxford University Press, https://doi.org/10.1093/actrade/9780199596652.001.0001

Amin, Samir, and Brian Pearce. 1974. "Accumulation on a world scale: A critique of the theory of underdevelopment." 2. New York: Monthly Review Press.

Arrighi, Giovanni. 2010. "The long twentieth century: Money, power, and the origins of our times." Verso: New and Updated Edition. L. and N.Y., $432 \mathrm{p}$.

Attali, Jacques. 2011. "A brief history of the future: a Brave and Controversial Look at the Twenty-First Century." Skyhorse Publishing Inc.

Blackwill R.D., J.M. Harris. 2016. "War by Other Means: Geoeconomics and Statecraft." Harvard University Press, Cambridge, MA, $224 \mathrm{p}$. https://doi.org/10.4159/9780674545960

Braudel, Fernand. 1984. "Civilization and capitalism, 15th-18th Century, Vol. I: The structure of everyday life." Vol. 1. Univ of California Press, 1992.

Chase-Dunn, Christopher K. 1979. "Comparative research on worldsystem characteristics." International Studies Quarterly 23(4): 601-623. https://doi.org/10.2307/2600333

Frank, Andre Gunder, Barry Gills, and Barry K. Gills, eds. 1996. "The world system: Five hundred years or five thousand?." Psychology Press.

R\&D World. Global R\&D investments unabated in spending growth. 2020 Global R\&D Funding Forecast. Available at: https://www.rdworldonline.com/global-rd-investmentsunabated-in-spending-growth/ (accessed 27.06.2020).
Kindleberger, Charles Poor. 1996. "World economic primacy: 15001990." Oxford University Press on Demand.

International Monetary Fund. World Economic Outlook Database. April 2020. Available at: https://www.imf.org/external/pubs/ $\mathrm{ft} /$ weo/2020/01/weodata/weorept.aspx?sy=2000\&ey $=2019 \& \mathrm{~s}$ $\mathrm{csm}=1 \& \mathrm{ssd}=1 \&$ sort=country\&ds=.\&br=1\&pr1.x=16\&pr1.y=8\& $c=001 \% 2 C 110 \% 2 C 200 \& s=P P P G D P \& g r p=1 \& a=1$ (accessed: 27.06.2020).

Lachininskii, S. S. 2012. "Current trends in geoeconomic studies in Russia." Regional research of Russia 2(1): 80-86. https://doi.org/10.1134/S2079970512010054

Luttwak, Edward N. 1990. "From geopolitics to geo-economics: Logic of conflict, grammar of commerce." The national interest 20: 17-23.

Maddison, Angus. 2007. "Contours of the world economy 1-2030 AD: Essays in macro-economic history." Oxford University Press. https://doi.org/10.1111/i.1467-8411.2005.00164.x-i1

Pomeranz, Kenneth. 2001."The great divergence: China, Europe, and the making of the modern world economy." Princeton University Press.

https://doi.org/10.1515/9781400823499

Savona, Paolo, and Carlo Jean, eds. 1997. Geoeconomia: il dominio dello spazio economico. FrancoAngeli 52: 84-140

Flint, Colin, and Peter J. Taylor. 2007. "Political geography: Worldeconomy, nation-state, and locality." Pearson education. Harlow: $355 \mathrm{p}$.

Wallerstein, Immanuel. 2011. "The modern world-system I: Capitalist agriculture and the origins of the European world-economy in the sixteenth century." Vol. 1. Univ of California Press. https://doi.org/10.1525/9780520948570

Wallerstein, Immanuel. 1980. "The modern world-system II: Mercantilism and the consolidation of the European worldeconomy, 1600-1750." Vol. 2. Univ of California Press.

Wallerstein, Immanuel. 1989. "The modern world-system III: The second era of great expansion of the capitalist worldeconomy, 1730s-1840s." Vol. 3. Univ of California Press,

Wallerstein, Immanuel. 2011. "The modern world-system IV: Centrist liberalism triumphant, 1789-1914." Vol. 4. Univ of California Press, 2011. https://doi.org/10.1525/9780520948600

World Bank Open Data. Goods exports. Available at https://data.worldbank.org/indicator/BX.GSR.MRCH.CD?mos t_recent_value_desc=true (accessed: 27.06.2020).

World Bank Open Data. High-technology exports. Available at: https://data.worldbank.org/indicator/TX.VAL.TECH.CD?end= $2018 \&$ most recent value desc $=$ true\&start $=2007$ (accessed at: 27.06.2020)

World Bank Open Data. Research and development expenditure (\% of GDP). Available at: https://data.worldbank.org/indicator/ GB.XPD.RSDV.GD.ZS?locations=OE\&view=chart (accessed: 27.06.2020)

Received on 29-11-2020

\section{DOI: https://doi.org/10.6000/1929-4409.2021.10.24}

(c) 2021 Alexey N. Yeletsky; Licensee Lifescience Global.

This is an open access article licensed under the terms of the Creative Commons Attribution Non-Commercial License (http://creativecommons.org/licenses/by-nc/3.0/) which permits unrestricted, non-commercial use, distribution and reproduction in any medium, provided the work is properly cited. 